\title{
Lexis
}

Journal in English Lexicology

3 | 2009

Borrowing

\section{Linguistic Borrowing in the English Language of Economics}

\author{
Magdalena Bielenia-Grajewska
}

\section{(2) OpenEdition \\ Journals}

\section{Electronic version}

URL: https://journals.openedition.org/lexis/643

DOI: $10.4000 /$ lexis.643

ISSN: 1951-6215

\section{Publisher}

Université Jean Moulin - Lyon 3

\section{Electronic reference}

Magdalena Bielenia-Grajewska, "Linguistic Borrowing in the English Language of Economics", Lexis [Online], 3 | 2009, Online since 27 July 2009, connection on 21 September 2021. URL: http:// journals.openedition.org/lexis/643 ; DOI: https://doi.org/10.4000/lexis.643

\section{(c) $\oplus \Theta \Theta$}

Lexis is licensed under a Creative Commons Attribution-NonCommercial-NoDerivatives 4.0 International License. 


\title{
Linguistic Borrowing in the English Language of Economics
}

Magdalena Bielenia-Grajewska ${ }^{1}$

\begin{abstract}
The aim of this paper is to discuss the function of loanwords in English economic discourse. In the introductory part, the author presents very briefly an inventory of foreign words used in English. Being a linguist and an economist, the author is interested in the language of economics and she will try to show how different languages have helped to shape the current economic lexicon in English. In this article, an attempt will be made to discuss which languages have influenced English economic vocabulary and which particular domains, such as technical analysis or options, rely heavily on loanwords. The author also discusses how borrowed lexical items determine the language of economics. The article finishes with an attempt to predict the future situation of borrowings in English business communication.
\end{abstract}

Keywords: borrowing - English - language of economics

\section{Résumé}

Le but de cet article est de montrer la fonction des mots empruntés dans le discours économique anglais. L'article commence par une courte présentation de l'origine des mots étrangers utilisés en anglais. Pour mener à bien son analyse, l'auteur limite son champ de recherches pour ne prendre en considération que la langue économique. Elle souligne la diversité des langues étrangères qui ont exercé une influence sur l'état actuel du vocabulaire économique anglais. L'auteur examine tour à tour chaque domaine de l'économie du point de vue de l'influence particulière d'une langue sur un domaine économique déterminé et en explique la raison. L'article s'achève par une réflexion sur le devenir des emprunts dans la communication commerciale anglaise.

Mots-clés : emprunt - anglais - discours économique

\footnotetext{
${ }^{1}$ University of Gdańsk, Poland.
} 


\section{Introduction - characteristics of the language of economics}

The language of economics serves many purposes. It provides the members of an economic community, such as customers, investors or bankers, with the tools needed to discuss various business issues. What is more, this sublanguage is not only used by specialists who belong to a restricted and linguistically homogeneous group, since we all take part in economic relations in direct and indirect ways. In short, the language of economics is closely related to general language use. This feature is also stressed by Katamba [2004: 168], who states that

sometimes the jargon of a specialist group seeps into the common language of the wider community. This is particularly likely to happen where the activities of that sub-group are fashionable or impinge directly on the life of the wider community.

This is certainly the case with the language of economics as economics as such determines much of our everyday life since we all take part in economic life by being employers, employees, customers etc.

Several important characteristics shape the current state of economic discourse. The most important feature is globalization, especially in the economic sphere. However, this process is not a new phenomenon since mercantile contacts were popular even in the communities which existed many centuries ago [Hirst and Thompson 2002: 335]. These commercial relations influenced the linguistic behavior of those community members. We should remember that goods, techniques or fashions, although very important in intercultural exchange, do not govern the structure of these cultures [Kellner and Soeffner 2003: 142]. It is the language itself which influences not only other tongues but also the way a given populace speaks. The most remarkable sources of these influences are loanwords.

As Milroy [1992: 81] states,

linguistic innovation is accomplished by persons who have many ties within the community but who simultaneously have a large number of outside contacts.

That is why so many loanwords appear in the language of economics, which is, and always was, determined by intercultural contacts as well as by inner communication within a given community.

\section{Loanwords}

With respect to the emergence of loanwords, Platt et al. [1984: 88] observe that linguistic contacts between languages result in the incorporation of some words coming from other tongues. Thus, the process of adopting foreign words is not monolithic. This process affects all languages, dialects, and jargons to different degrees and ways since the communities who speak those languages do not function in isolation.

There are several reasons why loanwords occur in languages. First of all, a new word is introduced into a target culture when it can be coherent with the incorporating environment [Usunier and Lee 2005: 36]. There are also several stages connected with adapting loanwords. The process as such depends on the following factors:

1) how the recipient language has developed;

2) to what extent speakers are "nationally conscious";

3) international preferences; 
4) philological knowledge and understanding difficulties in language comprehension [Baldunčiks 1991: 15].

As far as the borrowed words are concerned, we can classify their use by using the typology from Platt et al. [1984: 88-89]. The most popular words are:

1. occasionally but haphazardly used;

2. used more frequently by a number of speakers (stabilizing loan words);

3. used or recognized by most speakers (stabilized loan words).

In this work, I am focusing primarily on the terms known by most users, i.e. those with conventionalized status in the lexicon. My aim is to study the influence of foreign languages on English.

\section{Loanwords in English}

English is a language with a rich and diverse lexicon [Carter, Goddard, Reah, Sanger and Bowring 2001: 116]. English changes due to intensive contacts with other languages and language evolution, which is mirrored in such linguistic processes as compounding, functional shift, affixes or coinage [Gilsdorf 2002: 364]. As Greenough and Kittredge [2001: 108] state,

the enterprising spirit of the English people and their fondness for travel and colonization, as well as the great development of their commerce, have brought in miscellaneous words from every quarter of the world.

English has borrowed its lexicon from 84 languages, with French (25\%) being the most important donor. Other influent languages are Japanese, Spanish, African languages, German and Greek [Jackson and Ze Amvela 2002: 42]. There are different reasons why foreign languages have entered English. One of them is connected with trade or colonial occupation. That is why in the ninth century Scandinavian words became part of the English lexicon [Katamba 2004: 143]. The same applies to the role of Flemish/Dutch in creating Middle English. The Dutch expressions used in English business communication are dollar, groat, guilder and mart [Jackson and Ze Amvela 2002: 40]. Other languages also serve as a source of borrowings into English. For example, skunk was imported from the Algonquian family of languages [Thomason 2001: 91]. Some words connected with science or trading come from Eastern languages: algebra, almanac, amber, camphor, orange, saffron, syrup [Carter, Goddard, Reah, Sanger and Bowring 2001:116]. As Görlach [1999: 118] points out, foreign languages started to lose their impact on English from the beginning of the $19^{\text {th }}$ century. Thus, in the coming section, I will try to discuss whether they are still an important part of English. To narrow the scope of this research, I will concentrate only on the language of economics.

\section{Loanwords in the English language of economics}

\subsection{Research methods}

Many studies of the language of economics show the importance of English in the process of acquiring loanwords from other languages [e.g. Rosenhouse and Kowner 2008]. For example, there is research which underlines the role of English in shaping Latvian [Baldunčkiks 1991: 19], French business vocabulary [Battye, Hintze and Rowlett 2000: 302] or the German economic lexicon [Tribe 2007: 16]. The dominant position of English 
promotes globalization, and globalization reinforces the use of English [Tsuda 2008: 171]. However, in this paper an attempt will be made to show that not only does English determine the state of other languages, but also other languages influence the shape of English [Gilsdorf 2002: 364].

The complete list of collected terms consists of 300 words and phrases which come from different languages. The research material is classified according to the language the terms come from (appendix 1) and the area of economics they are used in (appendix 2). They were found in various books on economic issues which were printed between 1982 and 2008 (a detailed list of these materials is presented in the research materials section).

It should be noted that the economic lexicon comprises words coming from other areas of study, such as law, and thus its lexicon is not homogeneous. What is more, some economic terms became part of the standard lexicon. Consequently, some terms may be treated by some scientists as not necessarily purely economic. To prove that the discussed words and phrases represent economics, I compiled the corpus exclusively by taking into consideration books on economics or dictionaries of economic terms. These sources help us to discuss important trends in the development of the discussed modern English economic lexicon. As has been already stated, the aim of this research is to study language distribution within the English economic lexicon as well as to decide which languages determine each studied economic subdomain. The author groups all the discussed terms according to the language they come from, starting from the languages which donated the most terms (French, Latin, Japanese, Italian, Greek, Spanish, North Germanic Languages, German, Dutch, Yiddish, Assyrian, Persian, Korean). As far as the second research method is concerned, the following 12 categories have been suggested: general business, trade, management, human resources, marketing, accounting, finance (investment funds, securities and subtypes, such as stock market, shares, bonds, options, derivatives, technical analysis), banking (currency), insurance, business law, taxes and real estate (appendix 2). The etymological data denoting the century and the country the terms presented in appendix 1 come from have been gathered from the materials listed in the bibliography section.

\subsection{Research results}

It is commonly known that most of the loanwords in English come from French and classical languages [Gramley and Pätzold 2003: 29]. According to some studies, $75 \%$ of English vocabulary comes from French and Latin [Thomason 2001: 10]. The same feature has been proved in my research since French words constitute $41 \%$ of the 300 terms taken into consideration. The second language as far as linguistic input in English is concerned is Latin, which makes up $30 \%$ of the studied lexicon. The next one is Japanese with $13 \%$ of all studied terms. We can also find words of Greek (4\%), Italian (4\%), Spanish (2.3\%) and North Germanic (1.7\%) origin. The last group consists of such languages as Danish, Swedish and Old Norse. Other languages which have influenced the English economic lexicon are as follows: German (1.7\%), Dutch (0.7\%), Yiddish (0.7\%), Assyrian (0.3\%), Persian (0.3\%) and Korean $(0.3 \%)$. In the sections which follow I will discuss the most important linguistic donors in greater detail, by presenting some exemplary terms and taking into account the domain of economics which is shaped by a particular language.

\section{Loanwords from French}

French words started to appear in English in the eleventh century [Stockwell and Minkova 2001: 34]. One of the first words was treasury which was imported in 1137 [Cangeri 2007: 
10]. It is said that between 1066 and 1485 , about ten thousand words were incorporated into English, and about seven thousand of them became a part of the English lexicon [Thomas 2007: 138; Katamba 2004: 145]. During the reign of William I, French nobles took over from English officials and French started to represent a higher social status, whereas English was the language used among the masses [Fennell 2001: 106]. This process of French linguistic dominance started in 1066 and it influenced the vocabulary connected with economics and politics: duke, rent, market, cost, labor, calendar, pay [Hudson 2000: 248].

At this point, I turn to a discussion of what sort of French words entered the English lexicon. French, which tends to be associated with style and fashion, has had a remarkable influence on these domains in English. It is also noteworthy that French terms are used when some products or services are considered trendy as French words have been imported for their significance of high culture or social status [Lerer 2007: 68]. An example is the use of mobile for telephone instead of the Latin portable [Carter, Goddard, Reah, Sanger and Bowring 2001: 116] or using other French words in the domain of fashion: apparel, costume, or dress [Barber 2000: 147]. The relation between French and English is very dynamic. As Roey [1990: 113] states,

some lexical items have gone back and forth, i.e. were first borrowed in English from the French language, then disappeared in French but were later reintroduced from English. Budget (from Middle French bougette, diminutive form of bougesac, valise) is a case in point.

Owing to the limitations placed on this paper, I cannot discuss all the French loanwords which have heavily influenced many domains of economics. It is the first language donor in general business since almost $60 \%$ of terms in this domain are of French origin. The same situation is to be observed in trade, real estate, finance, accounting (about 50\%) and business law (almost 40\%). To provide the readers with some examples, I will first concentrate on those two domains which rely heavily on French loanwords, namely general business and finance, since French words constitute 54\% of all the studied terms in these domains. Price, being classified under the heading general business, comes from Old French prix, meaning value, excellence, money paid for something or esteem [Webster's II Dictionary Editors, 2004: 901]. To present one example from finance as well, let us discuss one of the words connected with trading in securities, namely arbitrage. As Edwards, Magee, Bassetti [2007: 744] state, it is

the simultaneous buying and selling of two different, but closely related instruments to take advantage of a disparity in their prices in one market or two different markets.

This French word comes from the verb "arbitrer", meaning to judge or estimate [Deutsch 2007: xiii]. As Freedman [2006: 6] points out, it entered the English language in the late $19^{\text {th }}$ century.

The next interesting term connected with financial instruments is coupon, which comes from the French couper, to cut.

These little cut-offs, which are really nothing more nor less when surrendered than an interest receipt on a time note - a substitute for a semi-annual or quarterly endorsement of interest paid - are, as their name indicates, a Continental importation [Patten 1980]. 
It should also be noted that French has influenced the coining of English words. In the domain of business, we have some French-sounding words, with the ending -iser, such as franchiser [Walter and Fawcett 1994: 208] or merchandiser. I will concentrate on the word entrepreneur, which comes from the French word "entreprendre" and means to undertake [Kao, Kao, Kao 2002: 32]. As far as the history of this word is concerned, it was formed in the Middle Ages to refer "to a person who is active, who gets things done". Richard Cantillon (1680-1734) added a new meaning to this concept by stating that entrepreneurs are speculators, traders and dealers, taking into account decision-making and risk [Souitaris 2009: 92]. In the early 1800s, Jean Baptiste Say presented a different perspective of the entrepreneur concept [Black and Rossi 2001: 7]. He used this name to describe people who create:

value in an economy by moving resources out of areas of low productivity, into areas of higher productivity and greater yield [Gupta and Khare 2006: 14].

As has been presented above, French words are also present in English business law terminology. One example can be the expression force majeure which means

an event outside the control of either party to a contract (such as a strike, riot, war, act of God) that may excuse either party from fulfilling his contractual obligations in certain circumstances, provided that the contract contains a force majeure case [Smullen 2005: 164].

This concept comes originally from the Napoleonic Code [Delmon 2005: 299].

Thus, we can state that French words can be found in many domains of economics, such as business and financial services, to name just two of them. Even today, French words are the most common loanwords in English. One of the reasons is geographical proximity [Jackson and Ze Amvela 2002: 43], whereas another one is to do with historical relations. To finish this part, we can quote Katamba, who states that we cannot do without French loanwords in English. It would be extremely difficult to talk for even a few minutes without using any word of foreign origin [Katamba 2004: 139]. This is especially visible in the domain of economics, even when English users do not pay attention to the above-mentioned linguistic phenomenon.

\section{Loanwords from Latin}

It is also clear that many loanwords which are thought to be imported from French come from Latin. Latin has been a source for loanwords borrowed directly in English but also some Latin words have been incorporated into English from French [Loewenthal 2008: 7]. That is why it is sometimes difficult to state whether a particular term is of French or Latin origin [Greenough and Kittredge 2001: 95]. A good example coming from intercultural communication of this is the word relation which can either be from French (relation) or from Latin (relatio) [Kuthe 2007: 11]. Let us discuss briefly the influence of Latin on English economic terms. After analyzing the terms of Latin origin, we can observe that Latin influences business law, currency and taxes (about 60\%), accounting (about 40\%), general business terminology, trade and finance (about 30\%). Latin terms are especially prominent in the legal aspects of economics. Even very basic legal documents were written by English lawyers and clerks in Latin [Greenough and Kittredge 2001: 100]. Note the following examples coming from business law. Caveat emptor means let the buyer beware. As far as legal terminology is concerned, it means that 
a buyer of goods should use his or her own common sense and that the law is not prepared to aid someone who buys goods foolishly [Clark and Hammett 2001: $71]$.

The second example quantum meruit - as much as he has earned-describes a situation when

a supplier only half-completes the work he or she has been contracted to do, the supplier may in some cases claim payment in proportion to the amount of work completed, known as payment quantum meruit [Kermode, Owen and Clark 2001: 259-260].

The third - ultra vires - is used to describe those who are beyond the powers of the company [Smith and Keenan 2004: 292].

Latin has also influenced the money sphere in the English-speaking world. The name money comes from Latin moneta, pound comes from pondus meaning weight, and cent is from centus [Greenough and Kittredge 2001: 139-140]. As far as securities are concerned, let us consider the word auction which comes from the Latin verb 'auctio' (from 'augere') which means 'to increase' [Hultmark, Ramberg, Kuner 2002: 44].

To sum up this section, it is noteworthy that Latin loanwords are especially prominent in the domains which have a long history of existence and date back to ancient times.

\section{Loanwords from Japanese}

As is commonly known, some Japanese words associated with war or military action have entered the English lexicon: samurai, karate, hara-kiri and kamikaze. Other common loanwords are origami, kimono, haiku, habuki and karaoke [Katamba 2004: 152]. According to some studies, Japanese is the second most productive source of new loanwords to English [Evans ix: 1997]. Nowadays, many Japanese terms enter the English economic lexicon, probably due to the commercial position of Japan in the world economy [Jackson and Ze Amvela 2002: 43]. There are many studies showing the English influence on Japanese marketing, especially in promotional materials [Usunier and Lee 2005: 37]. However, there are certain areas within the economic discourse where Japanese is of crucial importance. Japanese terms are used in management and finance (technical analysis and securities, mainly bonds). Let us discuss some examples. In particular, management philosophy employs such terms as genba-shugi, keiretsu and zaibatsu. Bird [2002: 162] states that genba-shugi means shop-floorism.

This is a management philosophy that dictates that, as far as possible, the process of production of goods and services must be controlled at the shop-floor level by shop people.

The group called keiretsu is outstanding owing to its

mutual shareholding among their constituent firms and consultation among the member firm's top managers,

but it is not as strict in form as zaibatsu was [Karan and Gilbreath 2005: 325]. Kanban, which literally means signboard, is a synonym for demand scheduling. Its aim is to minimize the cost connected with holding inventory [Gross 2003: 1]. Another useful term for 
management and production is the expression Taguchi method. As Norman [2006: 242] states, the Taguchi method is

the analysis of quality problems developed by Genichi Taguchi that involves removing variability and the effects of causes instead of the cause and focuses on robust process and product design and the identification of after-sales costs.

Another domain of interest that serves as a source of borrowing into English is technical analysis since in Japan technical analysis was of crucial importance even many centuries ago. In the seventeenth century, they traded empty rice contracts, which meant that they used rice in commercial contacts without handling rice physically [Nison 1995: 277].

Let us discuss some examples of technical analysis. It should be stated that these names are written in Romanji, which allows those not knowing Japanese to pronounce it in the right way [Morris and Litchfield 2006: 11]. To digress, their names are metaphorical in character. For example, as Shimizu [2007: 64] describes, the harami candlestick resembles a woman expecting a child (harami means pregnant in Japanese). Other Japanese terms, such as Marubozu (close-cut) and Doji (simultaneous or concurrent), are used in technical analysis as well. Japanese equivalents are also to be found in the instruments related to the Japanese market. For example, gensaki is

a yen repurchase agreement based on Japanese securities. The rates of gensaki agreement are set in line with the yen certificates of deposit market rate. Gensaki refers only to repurchase agreement available in Japan, not in overseas market [Carew 1996: 157].

To conclude this section on Japanese loanwords, it is clear that Japanese terms can be found in the English vocabulary connected with strategic management, technical analysis and financial instruments.

\section{Loanwords from Greek}

The influence of Ancient Greek on the culture and languages of many European languages is unquestionable. As Bien et al. [2004: 189] state,

thousands of words from ancient Greek entered Latin and then passed from Latin to the Romance languages. Thousands more travelled directly from Greece, especially to France, and from there once again to England. And of course medical science today continues to rely on Greek to name its procedures.

A significant number of the words of Greek origin can be found in the economic lexicon as well. The linguistic influence of Greek is connected with the history of investment possibilities. For example, the first instruments similar to the modern term options can be found in the Code of Hammurabi.

Twelve hundred years later, the Greek philosopher Thales invented an option contract that enabled him to purchase crops before they were planted [Taylor 2004: 167].

Nowadays, it is 
a custom in the options business to use Greek letters to quantify incremental, onedimensional aspects of our exposure. While these Greek letters tell us very little about the expected profitability of our option position, they are powerful, but imperfect, risk management tools [Powers 2001: 266].

For example, the kappa of an option measures the change in premium value for each $1 \%$ change in price volatility [Treat 2000: 190].

The expression rho describes how sensitive the option's price is to the change in interest rates, where phi shows how sensitive an option is when changes in the foreign interest rates occur. Powers [2001: 266] states that delta represents the change in the market price, whereas gamma is used to describe the rate of change in the delta.

Other terms of Greek origin can be found in the terminology connected with general business (economy), management (philotimo), human resources (charisma) and banking. For example, a banking word autarky or autarchy comes from the Greek word autarchia, meaning self-rule and in economic parlance it refers to national economic self-sufficiency [Carew 1996: 39].

\section{Loanwords from Italian}

Most people associate loanwords from Italian with music and cuisine [Carter, Goddard, Reah, Sanger and Bowring 2001: 116]. It is noteworthy, however, that we can also find some Italian loanwords in the English economic lexicon since the terms of Italian origin constitute about $4 \%$ of the studied lexicon. Even one of the basic words - management - comes form Italian maneggiare and refers to an equestrian's handling of a horse [Magala 2009: 172]. Italian words can be found especially in trade and finance. Let us discuss one term from securities - the term agio - which is an expression used in commercial relations to show the difference of price between the value of bank-notes [Bouvier and Rawle 1914: 163]. As we can read in the Standard Library Cyclopedia of Political, Constitutional, Statistical and Forensic Knowledge [Knight 1853: 61], it is

used to denote the difference between the real and nominal value of moneys. The Italian word agio means ease or convenience; but the Italian for agio, in the sense in which we use the word, is aggio, which is explained to mean "an exchange for money for which the banker has some consideration".

Another financial term, mostly associated by us with architecture, is mezzanine. As Welz [2007: 9] states,

mezzanino designates a mezzanine floor typical for the building method of the baroque and the renaissance between two main levels of a building.

It comes from the name mezzanine, which started to be used in 1331 to describe silver coins [Sargent and Velde 2002: 166]. Mezzanine financing describes lenders that provide funding for the niche market, between secured debt and significant sale of equity [Alterowitz and Zonderman 2007: 129]. Thus, its metaphorical character, betweenness, is stressed in the financial terminology as well since mezzanine financing describes capital between ordinary shares and senior debt financing [Timmons, Spinelli and Zacharakis 2005: 123]. 


\section{Loanwords from Spanish}

Many borrowings from Spanish started to enter the English lexicon in the sixteenth century. Many words which we use nowadays, not necessarily in business contacts, but in trade, are of Spanish origin: alligator (el lagarto, the lizard), avocado, barracuda, canoe, chocolate, cigar, cockroach, domino, embargo, mosquito (little fly), peccadillo, potato, sombrero, tobacco, tornado, tortilla and vanilla, some of them being used in trade [Jackson and Ze Amvela 2002: 40-41]. Spanish is widely spoken in the USA since more than $22,400,000$ people use this language and it is also an official language in New Mexico ${ }^{2}$. Consequently, its influence can be easily noticed in American English. The history of borrowing from Spanish is a long one, indeed. We note

medieval loanwords in the $1300 \mathrm{~s}$ and $1400 \mathrm{~s}$, ranging across the maritime and mercantile borrowings of the $1500 \mathrm{~s}, 1600 \mathrm{~s}$, and 1700s, to American words from the Old West in the 1800s and the language of Latino music in the 1900s, a great deal of the wealth of words in English is a borrowing of the linguistic treasures of Spanish

[American Heritage Dictionaries 2007: v].

Owing to Spain's military and economic supremacy on the sea in the past, nowadays certain maritime and commercial terms are still in use: armada, cargo and embargo [American Heritage Dictionaries 2007: v-x]. The last two words were also taken into consideration in the study.

Some Spanish words are often used in English metaphorical expressions and such terms can be found in general business. Bonanza, being a source of great wealth [Tottie 2002: 123], is used in such terms as economic bonanza or entrepreneurial bonanza, to describe periods of prosperity and economic growth. Another common word in corporate discourse is gambit. We use it to describe risky maneuver or ploy used in any sort of conflict or competition. This was originally a chess term. It seems to come from Spanish gambit, which is really from Italian and means sticking the leg out to trip someone up [American Heritage Dictionaries 2007: 97].

\section{Loanwords from North Germanic languages}

This group constitutes the loanwords from modern languages (Swedish, Danish) as well as Old Norse, which influenced English in the Middle Ages. North Germanic languages have influenced banking, general business and currency. One of the earliest borrowings is loan, which was incorporated into English from Old Norse in the $13^{\text {th }}$ century.

\section{Loanwords from German}

German words can be found in such domains as general business, currency and finance. Many words which have been borrowed from German into the standard lexicon are related to military terminology [Kaplan and Baldauf 1997: 70]. An example of this can also be found in the English economic lexicon - blitzkrieg tender offer - which is

\footnotetext{
${ }^{2}$ http://www.ethnologue.com/show_language.asp?code=spa
} 
a takeover offer that is intended to be so attractive that very few objections will arise and the takeover will occur swiftly (http://www.investopedia.com/terms/b/blitzkriegtenderoffer.asp).

The term bank is originally from German. Other German terms which are used very often are Bund and Bundesbank [Knapp 2005: 17]. It should be mentioned, however, that the history of some loanwords is very complicated, and the term bank is one such example. Bank comes from the Italian word banca, which means moneychanger's table. What is even more complicated, it originally came from the French banque, which has some origins in the German Bank.

Owing to commercial contacts, German has influenced the names of currencies. Dollar is from the Low German dahler, whereas shilling comes from the German schellen - to sound, to tinkle [Greenough and Kittredge 2001:140]. However, the origin of shilling is not clear since, according to some sources, it is of Scandinavian origin (this approach has been taken into consideration in this study).

\section{Conclusion}

As is commonly known, there are many loanwords from a variety of source languages which determine the shape of the current English economic lexicon. Words, like money, are tokens of value [Lippmann 2004: 37]. On the basis of the study conducted of 300 terms, we can state that different languages influence the economic lexicon. Only some of them were presented in a more detailed way, by taking the criterion of loanword numbers. It should be stated, however, that this research suffers from some potential shortcomings since the covered terms are classified in different ways in many sources as far as their etymology is concerned. Nevertheless, we are able to notice some language and domain peculiarities within the English language of economics. It is French which is the most visible language in the English economic lexicon, determining such economic sub-domains as administration, trade or accounting, whereas it is Latin which shapes business law. Japanese determines the lexicon of technical analysis, Spanish shapes trade, especially transport terminology, whereas Greek terms are used by option investors.

As far as the future situation is concerned, we can predict that the process of loanwords will impact both English as well as other languages. Taking English into consideration, Euro English - a language strongly influenced by other community languages - is an example of how other languages shape English. With globalization gaining in importance, we can predict that the role of other languages in shaping English will be more visible. We can also predict that languages whose linguistic influence on other tongues is not very remarkable now may well become stronger due to their better economic position.

\section{Bibliography}

Alterowitz Ralph and Zonderman Jon, Financing Your Business Made Easy, Madison, Entrepreneur Press, 2007.

American Heritage Dictionaries, Spanish Word Histories and Mysteries, Boston, Houghton Mifflin Company, 2007. 
BALDUNČIKS Juris, "West European Loanwords in Modern Latvian", in IVIR Vladimir, KAlOGJER A. Damir (Eds), Languages in contact and contrast: essays in contact linguistics, Berlin New York, Mouton de Gruyter, 1991: 15-24.

BARBER Charles Laurence, The English language: a historical introduction, Cambridge, Cambridge University Press, 2000.

BAtTye Adrian, Hintze Marie-Anne and Rowlett Paul, The French Language Today: A Linguistic Introduction, London and New York, Routledge, 2000.

Bien Peter, Gondicas Dimitri, Rassias John, KARANiKa Andromache and YiannaKouBIEN Chrysanthi, Greek Today: A Course in the Modern Language and Culture, Lebanon, University Press of New England, 2004.

BIRD Allan, Encyclopedia of Japanese Business and Management, New York, Routledge, 2002.

BLACK Samuel P. and Rossi John Paul, Entrepreneurship and Innovation in Automobile Insurance, New York, Routledge, 2001.

CANGERI Francesca, Anglicization of French Words, Norderstedt GRIN Verlag, 2007.

BouviER John and RAWLE Francis, Bouvier's Law Dictionary and Concise Encyclopedia, Kansas City, Vernon Law Book, 1914.

CAREw Edna, The Language of Money, Sydney, Allen \& Unwin Academic, 1996.

Carter Ronald, Goddard Angele, Reah Danuta, SANGer Keith and Bowring Maggie, Working with texts: a core introduction to language analysis, London, Routledge, 2001.

ClaRK John and Hammelt Mike, Dictionary of International Trade Finance, Cranbrook, Global Professional Publishing, 2001.

DeLMon Jeffrey, Project Finance, BOT Projects and Risk, The Hague, Kluwer Law International, 2005.

Deutsch Henry, Arbitrage - In Bullion, Coins, Bills, Stocks, Shares and Options, Orlando, Deutsch Press, 2007.

Edwards Robert D., Magee John and Basetti W. H. C., Technical Analysis of Stock Trends, Boca Raton, CRC Press Taylor \& Francis Group, 2007.

Evans Toshie M., A dictionary of Japanese loanwords, Westport CT, Greenwood Publishing Group, 1997.

Fennell Barbara A., A History of English: A Sociolinguistic Approach, Oxford and Malden, Blackwell, 2001.

FreEdMAN Roy S., Introduction to Financial Technology, Burlington, Elsevier, 2006.

GILSDORF Jeanette, "Standard Englishes and World Englishes: Living with a Polymorph Business Language", Journal of Business Communication, vol. 39, 2002: 364 - 378.

GöRLACH Manfred, English in Nineteenth-Century England: An Introduction, Cambridge, Cambridge University Press, 1999.

Gramley Stephan and Pätzold Kurt-Michael, A Survey of Modern English, London, Routledge, 2003.

Greenough James Bradstreet and KiTTREDGe George Lyman, Words and their ways in English speech, New York, Adamant Media Corporation, 2001.

Gross John M., Kanban Made Simple: Demystifying and Applying Toyota's Legendary Manufacturing Process, New York, AMACOM, 2003.

GuPTA Ishan and KHARE Rajat, Make the Move: Demystifying Entrepreneurship, New Delhi, Pustak Mahal, 2006.

Hirst Paul and ThOMPson Grahame, "The Limits to Economic Globalization", in Held David, McGREW Anthony (Eds), The Global Transformations Reader: An Introduction to the Globalization Debate, Cambridge, Polity Press, 2002.

http://www.investopedia.com/terms/b/blitzkriegtenderoffer.asp

http://www.ethnologue.com/show language.asp?code=spa 
HuDSON Alastair, Equity and Trusts, London, Routledge, 2005.

Hultmark Christina, RAMberg Christina and KunER Christopher, Internet marketplaces: the law of auctions and exchanges online, New York, Oxford University Press, 2002.

JACKSON Howard and ZE AMvela Etienne, Words, Meaning and Vocabulary: An Introduction to Modern English Lexicology, London, Continuum International Publishing Group, 2002.

KaO Raymond W.Y., KaO Kenneth R., KaO Rowland R., Entrepreneurism: A Philosophy and a Sensible Alternative for the Market Economy, London, Imperial College Press, 2002.

KAPLAN Robert B. and BALDAuf Richard B., Language Planning: From Practice to Theory, Clevedon, Multilingual Matters, 1997.

KARAN Pradyumna Prasad and GiLbREATH Dick, Japan in the Twenty-First Century: Environment, Economy, and Society, Lexington, University Press of Kentucky, 2005.

KATAMBA Francis, English Words: Structure, History, Usage, Abingdon, Routledge, 2004.

Kermode D. G., OWEN John and Clark Edward, 2001, Dictionary of International Business Terms, Canterbury, Financial World Publishing, 2001.

KNAPP Robbin D., German English Words: A Popular Dictionary of German Words Used in English, Lulu.com., 2005.

KNIGHT Charles, Standard Library Cyclopedia of Political, Constitutional, Statistical and Forensic Knowledge, Vol. 1, London, Henry G. Bohn, 1853.

Kellner Hansfried and SoefFner Hans-Georg, "Cultural Globalization in Germany", in Berger Peter L. and Huntington Samuel (Eds), Many Globalizations. Cultural Diversity in the Contemporary World, New York, Oxford University Press, 2003: 119145.

KUTHE Desirée, Latin Loanwords in English, Munich, GRIN Verlag, 2007.

LERER Seth, Inventing English: a portable history of the language, New York, Columbia University Press, 2007.

LipPManN Walter, Public Opinion, Mineola, Courier Dover Publications, 2004.

LOEWENTHAL Marc, The Latin Heart of English: English Vocabulary Practice Volume 1, Lulu.com, 2008.

Magala Slawek, "Management of Meaning", in YiAnNis Gabriel (Ed.), Organizing Words: A Critical Thesaurus for Social and Organization Studies, Oxford, Oxford University Press, 2009: 172-174.

MiLROY James, "The interpretation of language change", in RISSANEN Matti (Ed.), History of Englishes: New Methods and Interpretations in Historical Linguistics, Berlin, Walter de Gruyter, 1992.

MORRIS L. Gregory and LITCHFIELD Ryan, Candlestick Charting Explained: Timeless Techniques for Trading Stocks and Futures, New York, McGraw-Hill Professional, 2006.

Nison Steve, "An Introduction to Japanese Candlestick Charts", in SchWAGER Jack D. (Ed.), Technical Analysis, New York, John Wiley \& Sons Inc, 1995: 277- 296.

Norman Thomas, The Illustrated Dictionary of Business Administration, New Delhi, Lotus Press, 2006.

PatTen Claudius Buchanan, The Methods and Machinery of Practical Banking, New York, Arno Press, 1980.

Plate John, Weber Heidi, Ho M.L, The New Englishes: What are They? Abingdon, Routledge, 1984.

Powers Marc J., Starting Out in Futures Trading, New York, Mc Graw Hill, 2001.

Roey J. VAN, French-English Contrastive Lexicology: An Introduction, Louvain-la-Neuve, Peeters, 1990. 
RoSEnHOUSE Judith and Kowner Rotem, Globally Speaking: Motives for Adopting English Vocabulary in Other Languages, Clevedon, Mulilingual Matters, 2008.

SARGENT Thomas, VELDE François R., The big problem of small change, Princeton, Princeton University Press, 2002.

SHIMIzU Yosuke, "Reading Candlestick Charts", in KeLler David (Ed.), Breakthroughs in Technical Analysis: New Thinking from the World's Top Minds, New York, Bloomberg Press, 2007: 51-83.

SMITH Kenneth and Keenan Denis J., Smith \& Keenan's English Law, Harlow, Longman Publishing Group, 2004.

SMUlLen John and HAND Nicholas, A dictionary of finance and banking, Oxford, Oxford University Press, 2005.

SouITARIS Vangelis, "Entrepreneurship", in YIANNIS Gabriel (Ed.), Organizing Words: A Critical Thesaurus for Social and Organization Studies, Oxford, Oxford University Press, 2009: 91-93.

StOCKWEll Robert P. and Minkova Donka, English words: history and structure, Cambridge, Cambridge University Press, 2001.

TAYLOR Marc C., Confidence Games: Money and Markets in a World Without Redemption, Chicago, University of Chicago Press, 2004.

Thomason Sara G., Language Contact: An Introduction, Edinburgh, Edinburgh University Press, 2001.

Timmons Jeffry A., Spineldi Stephen and ZaCharakis Andrew, How to Raise Capital: Techniques and Strategies for Financing and Valuing Your Small Business, New York, McGraw-Hill Professional, 2005.

TоттіE Grunel, An introduction to American English, Malden, Wiley-Blackwell, 2002.

TrEat John Elting, Energy Futures: Trading Opportunities, Tulsa, Pennwell Corp., 2000.

TribE Keith, Strategies of Economic Order: German Economic Discourse, 1750-1950, New York, Cambridge University Press, 2007.

TSUDA Yukio, "The Hegemony of English and Strategies for Linguistic Pluralism: Proposing the Ecology of Language Paradigm", in ASANTE Molefi K, MiIKE Yoshitaka and YIN Jing (Eds), The Global Intercultural Communication Reader, New York, Routledge, $2008: 167-178$.

UsunIER Jean-Claude and LEE Julie, Marketing Across Cultures, Harlow, Pearson, 2005.

WALTER Henriette and FAWCETT Peter, French inside out: the worldwide development of the French language in the past, the present and the future, London and New York, Routledge, 1994.

Webster's iI Dictionary Editors, Webster's II New College Dictionary, Houghton, Mifflin Reference Books, 2004.

WELz Stefanie, Mezzanine financing, München, Grin Verlag, 2007.

\section{Research materials}

Buttler Brian, ButTler David and IsaACs Alan, A Dictionary of Finance and Banking, Oxford, Oxford University Press, 1997.

CLARK Edward, Dictionary of International Economics Terms, London, Lessons Professional Publishing, 2006.

DAVIDSON Alexander, How to understand the financial pages. A guide to money \& jargon, London, Kogan Page Limited, 2005. 
De Roover Raymond, Money, Banking and Credit in Mediaeval Bruges - Italian Merchant Bankers, Lombards and Money Changers - A Study in the Origins of Banking, Rinsland Press, 2007.

DowneS John and GoODMAN Jordan Elliot, Dictionary of Finance and Investment Terms, Hauppauge, Barron's Educational Series, 2006.

Eichengreen Barry J. and Flandreu Marc, The Gold Standard in Theory and History, New York, Routledge, 1997.

ESTES Ralph, Dictionary of Accounting, Boston, The Massachusetts Institute of Technology, 1985.

FiTCH Thomas P., Dictionary of banking terms, New York, Barron's Educational Series, 2000.

GastineaU Gary L. and Kritzman Mark P., The Dictionary of Financial Risk Management, New York, American Stock Exchange, 1999.

HARVEY Sylvia and CORNER John, Enterprise and Heritage: Crosscurrents of National Culture, London, Routledge, 1991.

Higgs Henry, Palgrave's Dictionary of political economy, New York, A. M. Kelley, 1963.

HoliHan Mary, The Complete Guide to Investing in Commodity Trading: How to Earn High Rates of Returns Safely, Ocala, Atlantic Publishing Group, 2008.

Keller David, Breakthroughs in Technical Analysis: New Thinking from the World's Top Minds, New York, Bloomberg Press, 2007.

Kermode D. G., Owen John and Clark Edward, Dictionary of International Business Terms, Canterbury, Financial World Publishing, 2001.

Khan-Panni Phillip and Swallow Deborah, Communicating Across Cultures: The Key to Successful International Business Communication, Oxford, How To Books, 2003.

KLEIN David A., The Strategic Management of Intellectual Capital, Woburn, ButterworthHeinemann, 1998.

KozIERKIEWICZ Roman, Dictionary of Business Terms, Warsaw, C. H. Beck, 2005.

LAW Jonathan, Dictionary of business and management, Oxford, Oxford University Press, 2006.

LEVINSON Jay Conrad, Guerrilla marketing for free: 100 no-cost tactics to promote your business and energize your profits, New York, Houghton Mifflin Harcourt, 2003.

LINDWIG Oliver, The Illustrated Dictionary of Management, New Delhi, Lotus Press, 2006.

MCKAY H. Dean and Shank P. T., Business Words You Should Know: From Accelerated Depreciation to Zero-Based Budgeting - Learn the Lingo of any Field, Avon, Adams Media, 2008.

MISHKIN Frederic, The Economics of Money, Banking and Finance, Boston, Pearson Education, 2001.

MorRIS Virginia B. and MorRIS Kenneth M., Standard \& Poor's Dictionary of Financial Terms, New York, McGraw-Hill, 2007.

Nison Steve, Beyond Candlesticks: New Japanese Charting Techniques Revealed, New York, John Wiley \& Sons Inc., 1994.

Norman Thomas, The Illustrated Dictionary of Business Administration, New Delhi, Lotus Press, 2007.

O'Connell Martin P., The Business of Options: Time-tested Principles and Practices, New York, John Wiley \& Sons, 2001.

Онмав Kenichi, The Mind of the Strategist: The Art of Japanese Business, New York, McGraw-Hill, 1982.

PARRY Tony, Reuters Financial Glossary, London, Pearson Education, 2003.

PETERSON Nora, Wall Street Lingo: Thousands of Investment Terms Explained Simply, Ocala, Atlantic Publishing Group, 2007. 
REHFELD John E., Alchemy of a Leader: Combining Western and Japanese Management Skills to Transform Your Company, New York, John Wiley and Sons, 1994.

SCHWAGER Jack D., Technical Analysis, New York, John Wiley \& Sons Inc., 1995.

SHIM Jae K. and Siegel Joel G., Dictionary of International Investment Terms, New York, Barron's Educational Series, Inc., 2001.

SMITH Courtney, Option Strategies: Profit-making Techniques for Stock, Stock Index, and Commodity Options, New Jersey, John Wiley \& Sons., 1996.

STATT David A., The Routledge Dictionary of Business Management, London, Routledge, 2004.

TAYLOR Francesca, Mastering Foreign Exchange \& Currency Options: A Practical Guide to the New Marketplace, Harlow, Pearson Education Limited, 2003.

TEAM OF EXPERTS, Advanced Learner's Dictionary of Accounting, New Delhi, Anmol Publications, Publishers \& Distributors, 2000.

THE SILVER LAKE EDITORS, Insurance Dictionary: What Means What when it Comes to Life, Health, Business, Home, Auto and other Coverages, California, Silver Lake Publishing, 2002.

Thomas Hugh M., The Norman Conquest: England After William the Conqueror, Plymouth, Rowman \& Littlefield, 2007.

WALKER Donald Anthony, Walras's market models, New York, Cambridge University Press, 1996.

WiERZBIEKA A. Understanding cultures through their key words: English, Russian, Polish, German, and Japanese, New York, Oxford University Press US, 1997.

\section{Additional etymological sources}

BLACK Henry Campbell, A dictionary of law: containing definitions of the terms and phrases of American and English jurisprudence, ancient and modern, New Jersey, The Lawbook Exchange, Ltd., 1991.

Brown Leslie, The New Shorter Oxford English Dictionary on Historical Perspectives, Oxford, Oxford University Press, 1993.

CAMERON Rondo, "Introduction", in CAMERON Rondo, BovyKIN V. I. (Eds) International banking, 1870-1914, New York, Oxford University Press US, 1991: 3-21.

http://www.encyclopedia.com http://www.etymonline.com/index.php?1=e\&p=4

Komorowska Ewa and Kustra Andrzej, "Money in Slavdom", American Behavioral Scientist, Vol. 45 No. 2, 2001: 272-281.

SkEAT Walter W., A Concise Etymological Dictionary of the English Language, New York, Cosimo, Inc., 2005.

WeEKLEY Ernest, An Etymological Dictionary of Modern English, New York, Courier Dover Publications, 1967. 


\section{Appendix 1}

Loanwords in the English language of economics (language distribution)

\section{French}

A la Criee (19c)

Account (18c)

Accountant (15/16c)

Accrual bond (15c)

Adjournment (18c)

Adverse selection (20c)

Advice note (13c)

Allonge (18c)

Ambush (17c)

Amortization (19c)

Anomie (19c)

Apprentice (14c)

Arbitrage (18c)

Archive (17c)

Assets (16c)

Assurance (14c)

Aval (16c)

Baccalaureate bond (20c)

Bailee (16c)

Bank (15c)

Bankrupt (16c)

Bargain (14c)

Barter (15c)

Beige book (19c)

Bourse (16c)

Boutique (18c)

Branch (14c)

Brasserie (19c)

Brochure (18c)

Broker (14c)

Budget (15c)

Bureaucracy (19c)

Butchery (13c)

Cabotage (19c)

Canvass (14c)

Card (15c)

Carousel (17c)

Carrier (14c)

Carte Blanche (18c)

Cartel (16c)

Cash (16c)

Cashier (16c)

Catalogue (15c)

Cestui Que Vie (16c)

Charge (16c)

Chattel (13c)

Chattel mortgage (20c)

Cheque (14c)

Clearing bank (20c)

Clientele effect (16c)

Clique (18c) 
Cliquet option (20c)

Commodity (15c)

Company (16c)

Conduit (14c)

Consignment (19c)

Consumption (14c)

Conveyance (15c)

Counterfeit (13c)

Coupon (19c)

Covenant (13c)

Credit (16c)

Debit (15c)

Depot (18c)

Derivative (16c)

Discount (17c)

Divest (20c)

Dividend (17c)

Domicile (19c)

Dragnet clause (20c)

Embezzle (16c)

Employee (19c)

Endorsement (19c)

Entrepot trade (19c)

Entrepreneur (19c)

Equity (14c)

Escrow (16c)

Estoppel (16c)

Exchequer stocks (20c)

Expense (17c)

Exposure (16c)

Factoring (20c)

Force majeure (19c)

Forfaiting (20c)

Fortune (14c)

Franchise (13c)

Fund (18c)

Futures (19c)

Giscard bond (20c)

Gnomes of Zurich (18c)

Gross (16c)

Invoice (16c)

Issue (19c)

Jerque note (20c)

Labour (14c)

Laches (16c)

Laissez-faire (19c)

Lien (16c)

Maginot spread (20c)

Mala fide purchaser (20c)

Mutual (14c)

Net (16c)

Option (18c)

Pension (16c)

Personnel (19c)

Price (13c) 
Profit (14c)

Prospectus (18c)

Puisne mortgage (20c)

Reimburse (17c)

Revenue (15c)

Route (20c)

Savings (18c)

Seigniorage (13c)

Sovereign debt (20c)

Surety bond (20c)

Tax (13c)

Tender (18c)

Tranche (20c)

Transaction (17c)

Treasury (14c)

Voucher (20c)

\section{Latin}

Acceptance supra protest (14c)

Ad Litem (18c)

Ad Referendum (18c)

Ad Valorem (17c)

Addendum (18c)

Administration (14c)

Affidavit (18c)

Affiliate (18c)

Agency (16c)

Agenda (20c)

Agent (16c)

Annuity (15c)

Ante-dating (16c)

Auction (17c)

Audit (15c)

Balance (14c)

Bill (17c)

Bona fide (16c)

Bona vacantia (18c)

Bonafide error (16c)

Bonus (18c)

Capital (13c)

Caveat (16c)

Caveat Emptor (16c)

Caveat vendito (16c)

Cent (16c)

Channel captain (20c)

Channel stuffing (20c)

Client (14c)

Concession (17c)

Consensus (19c)

Consigner (16c)

Consortium (19c)

Consulting (16c)

Consumer (14c)

Contra proferendum (20c)

Contract (14c) 
Convertible (20c)

Cooperation (14c)

Corporate (16c)

Cost (13c)

Counter (14c)

Crisis (16c)

Cum dividend (20c)

Currency (17c)

Custody (15c)

Data (17c)

Debenture (15c)

Debt (14c)

Depreciate (17c)

Duty (15c)

Euro (20c)

Export (17c)

Expropriation (15c)

Franc (14c)

Fungibles (17c)

Glamour stocks (20c)

Import (17c)

Inflation (14c)

Inter vivos trust (19c)

Interests (16c)

Invest $(17 \mathrm{c})$

Laesio enormis (20c)

Margin (19c)

Maturity (19c)

Median (20c)

Memorandum (15c)

Mercantile agency (19c)

Momentum oscillator (17c)

Money (13c)

Monopoly (16c)

Payroll (18c)

Per capita $(17 \mathrm{c})$

Portfolio (20c)

Pound (early borrowing)

Premium (17c)

Pro forma statement (20c)

Quantum meruit (17c)

Quasi contract (15c)

Quota (17c)

Quotation (17c)

Ratio (17c)

Salary (14c)

Security (16c)

Solus position (20c)

Solus site (20c)

Subpoena (15c)

Synergy (19c)

Uberrima fides (19c)

Ultra vires transaction (20c)

Vendor (16c) 
Japanese

Amae (20c)

Daimyo bond (20c)

Doji (17c)

Enryo (20c)

Gai- atsu (20c)

Geisha bond (19c)

Genba (20c)

Gensaki (20c)

Hara-kiri swap (19c)

Harami (20c)

Hirikomi (20c)

Hito- kane- mono (20c)

Irikubi (20c)

Ishikawa diagram (20c)

Itayose (20c)

Jittai (20c)

Joho shakai (20c)

Kabuse (20c)

Kamikaze pricing (20c)

Kanban (20c)

Kansei engineering (20c)

Karoshi (20c)

Keiretsu (20c)

Marubozu (20c)

Nakasone bond (20c)

Saitori (20c)

Samurai bond (18c)

Sashikomi (20c)

Shibosai bond (20c)

Shingo \& Seven Wastes (20c)

Shitakage (20c)

Shogun bond (20c)

Sushi bond (20c)

Takuri (20c)

Tanshi houses (20c)

Tokkin (20c)

Toyotism (20c)

Tsutsumi (20c)

Zaitech (20c)

\section{Italian}

Agio (14c)

Contango (19c)

Defalcation (19c)

Deposit (18c)

Giro (19c)

Loco (20c)

Management (16c)

Mezzanine (18c)

Nostro account (14/15c)

Ponzi scheme (20c)

Scenario analysis (19c)

Vostro account (14/15c) 


\section{Greek}

Alpha (14c)

Autarky (17c)

Beta (14c)

Charisma (17c)

Delta (Greek)

Economy (15c)

Gamma (15c)

Kappa (14c)

Lambda (14c)

Philotimo (20c)

Rho (14c)

Theta (20c)

\section{Spanish}

Bonanza (19c)

Cargo (17c)

Embargo (16c)

Gambit (19c)

Guerilla marketing (20c)

Maquiladora (20c)

Vanilla option (20c)

North Germanic Languages (Old Norse, Danish, Norwegian, Swedish)

Laggards (18c)

Loan $(13 \mathrm{c})$

Salesman (16c)

Shilling (8c)

Trustee $(17 \mathrm{c})$

\section{German}

Blitzkrieg tender offer (20c)

Dollar (16c)

Firm $(19 \mathrm{c})$

Hedge (20c)

Schatz bond (20c)

\section{Dutch}

Trade (14c)

Santa Claus rally (20c)

\section{Yiddish}

Gazump (20c)

Gazunder (20c)

Assyrian

Ziggurat (19c)

Korean

Chaebol (20c)

\section{Persian}

Bazaar (16c) 


\section{Appendix 2}

\section{Loanwords in the English language of economics (domain distribution)}

\section{General business}

Addendum (18c Latin)

Administration (14c Latin)

Affiliate (18c Latin)

Agency (16c Latin)

Agent (16c Latin)

Agenda (20c Latin)

Ante-dating (16c Latin)

Archive (17c French)

Bankrupt (16c French)

Bargain (14c French)

Barter (15c French)

Bazaar (16c Persian)

Bonanza (19c Spanish)

Branch (14c French)

Brasserie (19c French)

Brochure (18c French)

Bureaucracy (19c French)

Butchery (13c French)

Carousel (17c French)

Cash (16c French)

Cashier (16c French)

Catalogue (15c French)

Client (14c Latin)

Clientele effect (16c French)

Clique (18c French)

Commodity (15c French)

Company (16c French)

Concession (17c Latin)

Conduit (14c French)

Consortium (19c Latin)

Consulting (16c Latin)

Consumer (14c Latin)

Consumption (14c French)

Contract (14c Latin)

Conveyance (15c French)

Cooperation (14c Latin)

Corporate (16c Latin)

Counterfeit (13c French)

Crisis (16c Latin)

Data (17c Latin)

Economy (15c Greek)

Entrepreneur (19c French)

Exposure (16c French)

Firm (19c German)

Fortune (14c French)

Franchise (13c French)

Gambit (19c Spanish)

Gnomes of Zurich (18c French)

Invoice (16c French)

Labour (14c French)

Laissez-faire (19c French) 
Mala fide purchaser (20c French)

Memorandum (15c Latin)

Monopoly (16c Latin)

Price (13c French)

Profit (14c French)

Prospectus (18c French)

Route (20c French)

Transaction (17c French)

\section{Trade}

Adjournment (18c French)

Advice note (13c French)

Balance (14c Latin)

Blitzkrieg tender offer (20c German)

Boutique (18c French)

Cabotage (19c French)

Canvass (14c French)

Cargo (17c Spanish)

Carrier (14c French)

Cartel (16c French)

Caveat vendito (16c Latin)

Consigner (16c Latin)

Consignment (19c French)

Counter (14c Latin)

Depot (18c French)

Duty (15c Latin)

Embargo (16c Spanish)

Entrepot trade (19c French)

Export (17c Latin)

Escrow (16c French)

Import (17c Latin)

Jerque note (20c French)

Loco (20c Italian)

Maquiladora (20c Spanish)

Mercantile agency (19c Latin)

Salesman (16c Old Norse)

Trade (14c Dutch)

Vendor (16c Latin)

\section{Management}

Chaebol (20c Korean)

Gai- atsu (20c Japanese)

Genba (20c Japanese)

Hito- kane- mono (20c Japanese)

Ishikawa diagram (20c Japanese)

Joho shakai (20c Japanese)

Kanban (20c Japanese)

Kansei engineering (20c Japanese)

Keiretsu (20c Japanese)

Management (16c Italian)

Philotimo (20c Greek)

Shingo \& Seven Wastes (20c Japanese)

Synergy (19c Latin)

Toyotism (20c Japanese) 
4. Human resources

Amae (20c Japanese)

Anomie (19c French)

Apprentice (14c French)

Charisma (17c Greek)

Employee (19c French)

Enryo (20c Japanese)

Karoshi (20c Japanese)

Payroll (18c Latin)

Pension (16c French)

Personnel (19c French)

Salary (14c Latin)

\section{Marketing}

Ambush (17c French)

Channel captain (20c Latin)

Guerilla marketing (20c Spanish)

Solus position (20c Latin)

Solus site (20c Latin)

\section{Accounting}

Accountant (15/16c French)

Amortization (19c French)

Assets (16c French)

Audit (15c Latin)

Channel stuffing (20c Latin)

Gross (16c French)

Net (16c French)

Nostro account (14/15c Italian)

Quota (17c Latin)

Revenue (15c French)

Vostro account (14/15c Italian)

\section{Finance}

Broker (14c French)

Budget (15c French)

Capital (13c Latin)

Charge (16c French)

Cost (13c Latin)

Credit (16c French)

Debit (15c French)

Debt (14c Latin)

Depreciate (17c Latin)

Discount (17c French)

Divest (20c French)

Dividend (17c French)

Expense (17c French)

Factoring (20c French)

Forfaiting (20c French)

Inflation (14c Latin)

Interests (16c Latin)

Invest (17c Latin)

Margin (19c Latin)

Median (20c Latin)

Mezzanine (18c Italian) 
Ponzi scheme (20c Italian)

Pro forma statement (20c Latin)

Ratio (17c Latin)

Reimburse (17c French)

Savings (18c French)

Sovereign debt (20c French)

Tender (18c French)

Tranche (20c French)

Treasury (14c French)

Voucher (20c French)

Zaitech (20c Japanese)

Ziggurat (19c Assyrian)

7.1 Investment fund

Hedge (20c German)

Mutual (14c French)

Tokkin (20c Japanese)

Trustee (17c Old Norse)

\subsection{Securities}

\subsubsection{Stock market}

A la Criee (19c French)

Auction (17c Latin)

Bourse (16c French)

Itayose (20c Japanese)

Kamikaze pricing (20c Japanese)

Laggards (18c Norwegian)

Momentum oscillator (17c Latin)

Saitori (20c Japanese)

Santa Claus rally (20c Dutch)

\subsubsection{Securities (general)}

Agio (14c Italian)

Allonge (18c French)

Annuity (15c Latin)

Arbitrage (18c French)

Beige book (19 c French)

Bill (17c Latin)

Domicile (19c French)

Endorsement (19c French)

Gensaki (20c Japanese)

Issue (19c French)

Maturity (19c Latin)

Portfolio (20c Italian)

Premium (17c Latin)

Quotation (17c Latin)

Security (16c Latin)

\subsubsection{Shares}

Equity (14c French)

Exchequer stocks (20c French)

Glamour stocks (20c Latin)

\subsubsection{Bonds}


Accrual bond (15c French)

Baccalaureate bond (20c French)

Convertible (20c Latin)

Coupon (19c French)

Cum dividend (20c Latin)

Daimyo bond Japanese (20c Japanese)

Debenture (15c Latin)

Geisha bond (19c Japanese)

Giscard bond (20c French)

Maginot spread (20c French)

Nakasone bond (20c Japanese)

Samurai bond (18c Japanese)

Schatz bond (20c German)

Shibosai bond (20c Japanese)

Shogun bond (20c Japanese)

Surety bond (20c French)

Sushi bond (20c Japanese)

\subsubsection{Options}

Alpha (14c Greek)

Beta (14c Greek)

Cliquet option (French)

Delta (Greek)

Gamma (15c Greek)

Kappa (14c Greek)

Lambda (14c Greek)

Option (18c French)

Rho (14c Greek)

Scenario analysis (19c Italian)

Theta (20c Greek)

Vanilla option (20c Spanish)

\subsubsection{Derivatives}

Contango (19c Latin)

Derivative (16c French)

Futures (19c French)

Hara-kiri swap (19c Japanese)

\subsubsection{Technical analysis}

Doji Japanese (17c Japanese)

Harami (20c Japanese)

Hirikomi (20c Japanese)

Irikubi (20c Japanese)

Jittai (20c Japanese)

Kabuse (20c Japanese)

Marubozu (20c Japanese)

Sashikomi (20c Japanese)

Shitakage (20c Japanese)

Takuri (20c Japanese)

Tsutsumi (20c Japanese)

\section{Banking}

Account (18c French)

Autarky (17c Greek)

Bank (15c French) 
Card (15c French)

Cheque (14c French)

Clearing bank (20c French)

Defalcation (19c Latin)

Deposit (18c Latin)

Giro (19c Italian)

Loan (13c Old Norse)

Per capita (17c Latin)

Seigniorage (13c French)

Tanshi houses (20c Japanese)

\subsection{Currency}

Cent (16c Latin)

Currency (17c Latin)

Dollar (16c German)

Euro (20c Latin)

Franc (14c Latin)

Fund (18c French)

Money (13c Latin)

Pound (early borrowing Latin)

Shilling (8c Danish)

\section{Insurance}

Adverse selection (20c French)

Assurance (14c French)

Uberrima fides (19c Latin)

\section{Business law}

Acceptance supra protest (14c Latin)

Ad Litem (18c Latin)

Ad Referendum (18c Latin)

Affidavit (18c Latin)

Aval (16c French)

Bailee (16c French)

Bona fide (16c Latin)

Bonafide error (16c Latin)

Bona vacantia (18c Latin)

Carte Blanche (18c French)

Caveat (16c Latin)

Caveat Emptor (16c Latin)

Cestui Que Vie (16c French)

Consensus (19c Latin)

Contra proferendum (20c Latin)

Covenant (13c French)

Custody (15c Latin)

Embezzle (16c French)

Estoppel (16c French)

Expropriation (15c Latin)

Force majeure (19c French)

Fungibles (17c Latin)

Laches (16c French)

Lien (16c French)

Quantum meruit (17c Latin)

Quasi contract (15c Latin)

Subpoena (15c Latin) 
Ultra vires transaction (20c Latin)

\section{Taxes}

Ad Valorem (17c Latin)

Bonus (18c Latin)

Tax (13c French)

12. Real estate

Chattel (13c French)

Chattel mortgage (20c French)

Dragnet clause (20c French)

Gazump (20c Yiddish)

Gazunder (20c Yiddish)

Inter vivos trust (19c Latin)

Laesio enormis (20c Latin)

Puisne mortgage (20c French) 